\title{
Insulin down-regulates insulin receptor substrate-2 expression through the phosphatidylinositol 3-kinase/Akt pathway
}

\author{
Y Hirashima*, K Tsuruzoe*1, S Kodama, M Igata, T Toyonaga, \\ K Ueki ${ }^{1}$, C R Kahn ${ }^{1}$ and E Araki \\ Department of Metabolic Medicine, Graduate School of Medical Sciences, Kumamoto University, 1-1-1 Honjo, Kumamoto, 860-8556, Japan \\ ${ }^{1}$ Research Division, Joslin Diabetes Center, Department of Medicine, Harvard Medical School, One Joslin Place, Boston, Massachusetts, 02215, USA \\ (Requests for offprints should be addressed to E Araki; Email: earaki@kaiju.medic.kumamoto-u.ac.jp) \\ ${ }^{*}(\mathrm{Y}$ Hirashima and K Tsuruzoe contributed equally to this work)
}

\begin{abstract}
Insulin receptor substrate (IRS)-1 and IRS-2 are the major substrates that mediate insulin action. Insulin itself regulates the expression of the IRS protein in the liver, but the underlying mechanisms of IRS-1 and IRS-2 regulation are not fully understood. Here we report that insulin suppressed the expression of both IRS-1 and IRS-2 proteins in Fao hepatoma cells. The decrease in IRS-1 protein occurred via proteasomal degradation without any change in IRS-1 mRNA, whereas the insulin-induced suppression of IRS-2 protein was associated with a parallel decrease in IRS-2 mRNA without changing IRS-2 mRNA half-life. The insulin-induced suppression of IRS-2 mRNA and protein was blocked by the phosphatidylinositol (PI) 3-kinase inhibitor, LY294002, but not by the MAP kinase-ERK kinase (MEK) inhibitor,
\end{abstract}

PD098059. Inhibition of Akt by overexpression of dominant-negative Akt also caused complete attenuation of the insulin-induced decrease in IRS-2 protein and partial attenuation of its mRNA down-regulation. Some nuclear proteins bound to the insulin response element (IRE) sequence on the IRS-2 gene in an insulindependent manner in vitro, and the binding was also blocked by the PI 3-kinase inhibitor. Reporter gene assay showed that insulin suppressed the activity of both human and rat IRS-2 gene promoters through the IRE in a PI 3-kinase-dependent manner. Our results indicate that insulin regulates IRS-1 and IRS-2 through different mechanisms and that insulin represses IRS-2 gene expression via a PI 3-kinase/Akt pathway.

Journal of Endocrinology (2003) 179, 253-266

\section{Introduction}

Type 2 diabetes is caused by the impaired action of insulin, an essential hormone for maintaining glucose homeostasis. Insulin initiates its biological effects by binding to and activating its endogenous receptor tyrosine kinase, the insulin receptor (IR) (Hendricks et al. 1984). Insulin receptor substrate (IRS)-1 and IRS-2 are the two major receptor substrate proteins in most cells (Sun et al. 1991, 1995). Mice lacking IRS-1 or IRS-2 secondary to gene disruption show insulin resistance, confirming the indispensable role of IRS-1 and IRS-2 in normal insulin action in peripheral tissues (Waterfield \& Greenfield 1991, Araki et al. 1994, Withers et al. 1998). More importantly, a high proportion of mice with a combined heterozygous defect in IR, IRS-1 and/or IRS-2 have diabetes, even though they have $50 \%$ of the normal concentrations of these molecules (Bruning et al. 1997, Kido et al. 2000). We also recently reported that the expression of IR, IRS-1 and IRS-2 was significantly decreased in obese IRS-1 heterozygous defective mice (Shirakami et al. 2002). These results suggest that not only the absence but also a decrease in IRS-1 and IRS-2 protein may contribute to the pathogenesis or progression of diabetes.

The liver is the major insulin target organ responsible for control of glucose homeostasis in the fasting state (DeFronzo 1997). Insulin signalling via the phosphatidylinositol (PI) 3-kinase pathway is a major mediator of the metabolic actions of insulin (Kanai et al. 1993, Cheatham et al. 1994, Dorrestijn et al. 1996). Both IRS-1-associated and IRS-2-associated PI 3-kinase activities are stimulated following insulin treatment of the liver; however IRS-2 signalling seems to be more important, since total insulin-induced PI 3-kinase activation is still near normal in the liver of IRS-1-deficient mice (Araki et al. 1994, Yamauchi et al. 1996, Withers et al. 1998). Low IRS-1 and IRS-2 protein levels have been found in patients with insulin resistance such as obesity and type 2 diabetes (Goodyear et al. 1995, Rondinone et al. 1997, Friedman et al. 1999) and in animal models with insulin resistance in multiple insulin-sensitive tissues, including the liver (Saad et al. 1992, Kerouz et al. 1997, Anai et al. 1998, Jiang et al. 1999, Shimomura et al. 2000), suggesting that the low expression level of IRS-2, and to a lesser 
extent of IRS-1 expression, in the liver contributes to abnormal glucose homeostasis. Although the regulation of IRS-1 has been well studied (Araki et al. 1995, Saad et al. 1995, Matsuda et al. 1997, Sun et al. 1999, Haruta et al. 2000, Lee et al. 2000), little is known about the mechanisms that control IRS-2 protein levels in normal or abnormal states such as insulin resistance and diabetes. It has been reported that hyperinsulinaemic animal models, such as ob/ob mice and Zucker fatty rats, have low IRS-1 and IRS-2 protein levels in the liver (Saad et al. 1992, Gerfen et al. 1995, Anai et al. 1998, Shimomura et al. 2000). In contrast, the liver-specific knockout of the insulin receptor (LIRKO) mice, in which insulin signalling in hepatocytes is selectively impaired, show a marked increase in IRS-2 levels in the liver (Michael et al. 2000). These observations suggest that, as with IRS-1, insulin itself may be a major regulator of IRS-2 protein levels in the liver.

The present study was designed to determine the mechanism(s) of insulin effects on IRS-2 expression, and the potential signalling pathway(s) involved in such regulation. Studies were conducted using Fao rat hepatoma cells treated with insulin.

\section{Materials and Methods}

\section{Materials}

Antibody to IRS-1 was prepared as described previously (Sun et al. 1991). Polyclonal antibody to IRS-2 was purchased from Upstate Inc. (Waltham, MA, USA). Polyclonal antibodies to Akt, phospho-specific Akt (Ser 473), MAP kinase and phospho-specific MAP kinase (Tyr 204) were from New England Biolabs, Inc. (Beverly, MA, USA).

$\mathrm{dCTP}$ and $\left[\gamma_{-}{ }^{32} \mathrm{P}\right] \mathrm{ATP}$ were purchased from New England Nuclear Inc. (Woburn, MA, USA). Immunoblotting apparatus was from Bio-Rad Laboratories (Richmond, CA, USA); the enhanced chemiluminescence (ECL) Western blotting kit was from Roche (Indianapolis, IN, USA) and ExpressHyb Hybridisation Solution was from Clontech (Palo Alto, CA, USA). PD098059 was from New England Biolabs, Inc. and MG132 was from Calbiochem-Novabiochem Corp (La Jolla, CA, USA). FUGENE 6 transfection reagent was from Roche. The Dual-Luciferase Reporter Assay System and the internal control plasmid pRL-TK were from Promega (Madison, WI, USA). PicaGene control vector, PGV-C2, was from Toyo Ink (Tokyo, Japan). Terminator sequencing mix was from Applied Biosystems-Perkin Elmer (Weiterstadt, Germany). All other common materials were from Sigma Chemical Co. (St Louis, MO, USA).

\section{Construct of recombinant adenovirus}

The adenovirus carrying dominant-negative Akt (DNAkt/Akt-AA; substituted Thr 308 to Ala and Ser 473 to
Ala) was constructed as described previously (Kitamura et al. 1998). The recombinant adenovirus was constructed by homologous recombination between the parental virus genome and the expression cosmid cassettes as described previously (Jones \& Persaud 1998). The adenovirus with the same parental genome carrying the $L a C Z$ gene was used as a control.

\section{Cell culture and adenovirus-mediated gene transfer}

Fao cells were maintained on $150 \mathrm{~mm}$ diameter dishes in 1640 RPMI (Gibco) medium Fetal Bovine Serum with $10 \%$ at $37{ }^{\circ} \mathrm{C}$ and $5 \% \mathrm{CO}_{2}$. The medium was changed every 2 days, and the cells were split every 7 days. For all assays, the cells were seeded into $60 \mathrm{~mm}$ dishes and cultured until confluent. For adenovirus-mediated gene transfer, Fao cells were cultured on $60 \mathrm{~mm}$ dishes. Confluent cells were incubated in $300 \mu \mathrm{l}$ media containing the adenoviruses for $1 \mathrm{~h}$ at $37^{\circ} \mathrm{C}$, and then $4 \mathrm{ml}$ RPMI medium supplemented with 10\% FBS were added, and the cells were further cultured for $24 \mathrm{~h}$. Next, the cells were serum-starved overnight, and then subjected to the assays described below. The adenoviruses were applied at a concentration of $3 \times 10^{8}$ plaque-forming units (PFU)/ $\mathrm{cm}^{2}$. The expression level of DN-Akt was determined by Western blot analysis with polyclonal Akt antibody, which recognizes both endogenous and transfected Akt.

\section{Western blot analysis}

For all experiments, cells were serum-deprived overnight in a medium containing $0 \cdot 1 \%$ BSA and then, unless noted otherwise, incubated with or without insulin at a concentration of $100 \mathrm{nmol} / 1$ in RPMI medium supplemented with $0 \cdot 1 \%$ BSA for the indicated time periods. In some cases, MG132 $(50 \mu \mathrm{mol} / \mathrm{l})$, PD098059 $(50 \mu \mathrm{mol} / \mathrm{l})$ and/or LY294002 $(50 \mu \mathrm{mol} / \mathrm{l})$ were added $30 \mathrm{~min}$ before the addition of insulin. Whole cell protein extracts were prepared by using buffer A (50 mmol/1 HEPES ( $\mathrm{pH} 7 \cdot 5)$, $150 \mathrm{mmol} / 1 \mathrm{NaCl}, 1 \mathrm{mmol} / \mathrm{l} \mathrm{EDTA}, 2 \mathrm{mmol} / 1 \mathrm{Na}_{3} \mathrm{VO}_{4}$, $20 \mathrm{mmol} / \mathrm{l} \quad \mathrm{Na}_{4} \mathrm{P}_{2} \mathrm{O}_{2}, 100 \mathrm{mmol} / \mathrm{l} \mathrm{NaF}, 1 \% \mathrm{NP}-40$, $2 \mathrm{mmol} / 1$ phenylmethylsulphonyl fluoride (PMSF), $20 \mu \mathrm{g}$ aprotinin $/ \mathrm{ml}$, and $10 \mu \mathrm{g}$ leupeptin/ml) for $30 \mathrm{~min}$ at $4{ }^{\circ} \mathrm{C}$, and insoluble protein was removed by centrifugation at $22000 \mathrm{~g}$ in a microcentrifuge. Protein content was determined by the method of Bradford (1976). The extract was then resolved directly in SDS-polyacrylamide gels after boiling in Laemmli SDS sample buffer. Approximately $50 \mu \mathrm{g}$ protein samples were separated by SDSpolyacrylamide gel electrophoresis (SDS-PAGE) and transferred to PVDF membrane. The membrane was subjected to Western blotting with a Western blotting kit according to the instructions provided by the manufacturer. The immunoreactive bands were visualized by enhanced chemiluminescence and quantified by densitometric analysis. 


\section{Northern blot analysis}

Cells were serum-deprived overnight and then, unless noted otherwise, incubated with or without $100 \mathrm{nmol} / 1$ insulin for the indicated times as mentioned in the description of Western blot analysis. In some cases, cycloheximide $(5 \mu \mathrm{g} / \mathrm{ml})$, PD098059 (50 $\mu \mathrm{mol} / \mathrm{l})$ and/or LY294002 $(50 \mu \mathrm{mol} / \mathrm{l})$ were added $30 \mathrm{~min}$ before the addition of insulin. Total RNA was isolated using TRIzol reagent (GIBCO-BRL, Gaithersburg, MD, USA). Approximately $20 \mu \mathrm{g}$ total RNA were subjected to electrophoresis in $1 \%$ agarose gel. Ethidium bromide staining of the gel confirmed equal loading and integrity of the RNA. Northern blot analysis for IRS-1, IRS-2 and 36B4 (internal control) was performed as described previously (Tsuruzoe et al. 2001).

\section{Half-life studies of IRS-1 and IRS-2 $m R N A s$}

Confluent Fao cells were serum-deprived overnight in RPMI medium containing 0.1\% BSA. After pretreatment with actinomycin D $(5 \mu \mathrm{g} / \mathrm{ml})$ for $15 \mathrm{~min}$, cells were incubated with or without $100 \mathrm{nmol} / 1$ insulin for 0-90 min in the presence of actinomycin D. IRS-1, IRS-2 and 36B4 mRNA levels were measured by Northern blot analysis as described above.

\section{Electrophoretic mobility shift assay}

A fragment corresponding to the sequence at nt -585 to -557 (5'-GAGTCACATGTTGTTTTGCTCTTCT TAGT-3' and 5'-ACTAAGAAGAGCAAAACAACAT GTGACTC-3') of the human IRS-2 gene promoter (Iwamoto et al. 2002) was used as a probe for the electrophoretic mobility shift assay (EMSA). The probe was end-labelled with $\left[\gamma-{ }^{32} \mathrm{P}\right] \mathrm{ATP}$ using T4 polynucleotide kinase prior to the analysis. Nuclear extracts were purified from Fao cells as described previously (Gorski et al. 1986). Approximately $1.0 \times 10^{4}$ c.p.m. of ${ }^{32} \mathrm{P}-$ labelled probe were added to the nuclear extract, and incubated with $1 \mathrm{mg}$ poly $(\mathrm{dI}-\mathrm{dC})$ in a binding buffer $\left(50 \mathrm{mmol} / 1 \mathrm{KCl}, 20 \mathrm{mmol} / 1 \mathrm{~K}_{3} \mathrm{PO}_{4}(\mathrm{pH} 7 \cdot 4), 6 \mathrm{mmol} / 1\right.$ $\mathrm{MgCl}_{2}, \quad 1 \mathrm{mmol} / 1 \quad \beta$-mercaptoethanol, 20\% glycerol, $0.5 \mathrm{mmol} / 1$ dithiothreitol, and $0.05 \mathrm{mmol} / 1 \mathrm{PMSF})$ at room temperature for $30 \mathrm{~min}$. In the competition assay, an excess amount (500-fold) of non-labelled DNA fragment was added before addition of the nuclear extract. DNAprotein complexes were resolved on $4 \%$ polyacrylamide gel with $0.5 \times$ Tris-Borate-EDTA buffer. The gel was dried and (0.045 M Tris-Borate, 0·001 M EDTA, pH 7·5 autoradiographed with an intensifying screen (Furukawa et al. 1999).

\section{Cloning of the partial rat IRS-2 gene promoter}

A partial rat IRS-2 gene promoter fragment was obtained by polymerase chain reaction (PCR) amplification using a genomic DNA from Fao cells or Wistar rats as a template. PCR primer pairs A-1: 5'-ACAGTTTACACAAAGGG TAAAGCATCTAT-3' (forward) and A-2: 5'-AACTG CTGCTTTGAATTTCTCTATCTAC-3' (reverse), and B-1: 5'-TAAGATAAACTCTGGTCCTGAATTGTT TCA-3' and B-2: 5'-TGCTGGCGTAGGAAAATGC GGTTTCCATAG-3' were designed based on the mouse IRS-2 gene sequence (White 1998). PCR conditions were as follows: denature, $96{ }^{\circ} \mathrm{C}, 2 \mathrm{~min}$, annealing, $55^{\circ} \mathrm{C}$, $2 \mathrm{~min}$, and extension, $72^{\circ} \mathrm{C}, 6 \mathrm{~min}$. Sequences of PCR fragments were determined by the ABI PRISM 310 Genetic Analyser.

Transient transfection of Fao cells and assay of luciferase activity.

Luciferase reporter plasmids, pGL3-IRS2 ( - 834), pGL3IRS2 ( - 1824) and pGL3-IRS2 ( - 2116), which contain various lengths of the human IRS-2 gene promoter, $(-834 \sim-124,-1824 \sim-124,-2116 \sim-124$ respectively) were kindly provided by Dr M Hashiramoto (Kobe University, Kobe, Japan). For the construction of luciferase reporter plasmids with partial rat IRS-2 gene promoter, a 398-bp fragment obtained by PCR with primers A-1 and A-2 was inserted at the SmaI site of pGV-C2 plasmids designed as PGV-C2-RatIRS2. The day before transfection, cells were transferred to $12-$ well culture dishes $\left(2 \times 10^{5}\right.$ cells/well $)$ to achieve 70 to $80 \%$ confluence at the time of transfection. Cells were transfected with $500 \mathrm{ng}$ luciferase reporter construct DNA and $50 \mathrm{ng}$ of the internal control plasmid pRL-TK with the use of FUGENE 6. Cells were serum-deprived for $8 \mathrm{~h}$ and then incubated with or without insulin at a concentration of $100 \mathrm{nmol} / 1$ overnight. In some experiments, LY294002 was added $30 \mathrm{~min}$ before insulin stimulation. The cell lysates were assayed sequentially for firefly and Renilla luciferase activities with the Dual-Luciferase Reporter Assay System.

\section{Statistical analysis}

Data are expressed as means \pm standard error of the mean (S.E.M.). Differences between two groups were evaluated by unpaired Student's $t$-test. $P<0 \cdot 05$ denoted the presence of a statistically significant difference.

\section{Results}

Insulin regulates IRS-1 and IRS-2 levels in Fao cells

To examine the effects of insulin on IRS-1 and IRS-2 protein expression, serum-starved Fao cells were incubated without or with variable concentrations of insulin for $24 \mathrm{~h}$, and the protein levels of IRS-1 or IRS-2 were determined by immunoblotting with anti-IRS-1 or 
A

Insulin $(\mathrm{nmol} / \mathrm{l}) \quad 0 \quad 0.1 \quad 1 \quad 10 \quad 10^{2} 10^{3}$

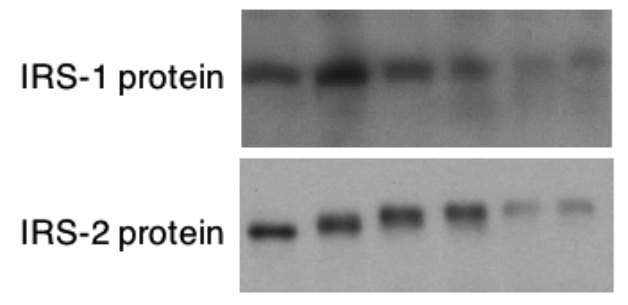

B

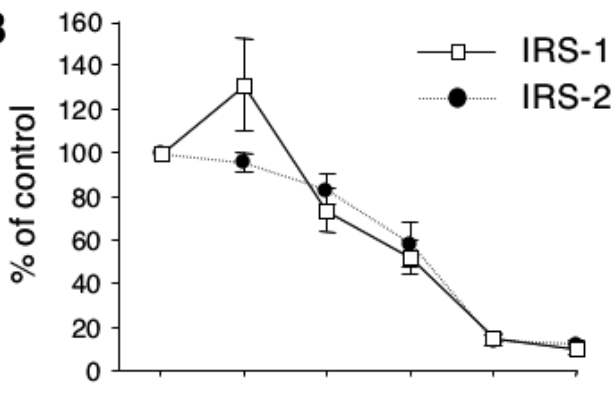

C

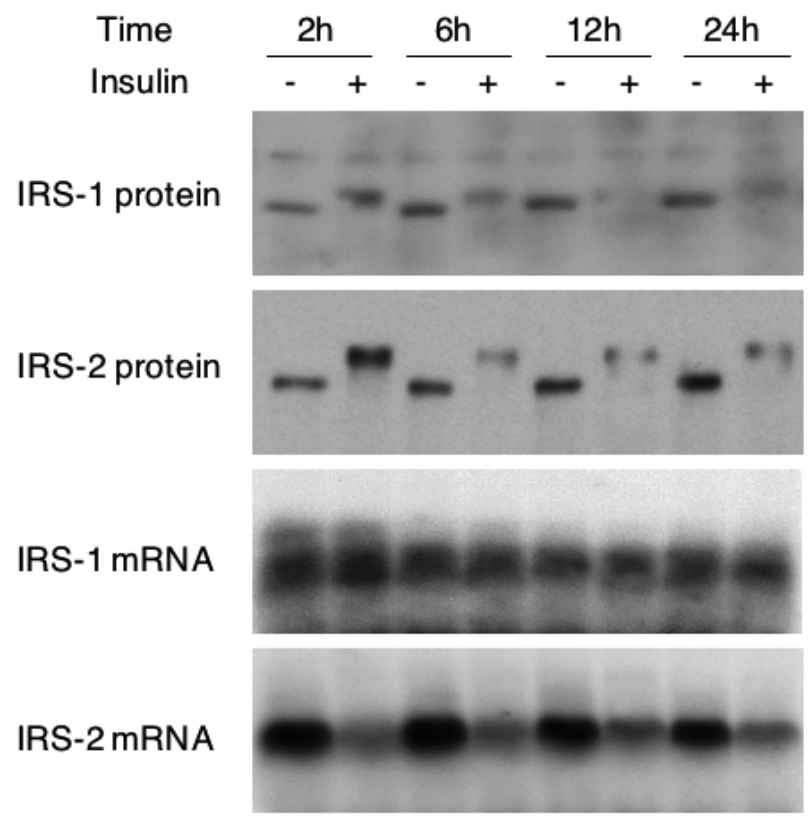

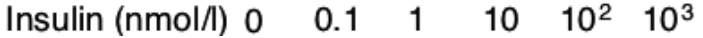

Figure 1 Effects of insulin on IRS-1 and IRS-2 proteins. (A) Serum-starved Fao cells were incubated with or without insulin at various concentrations for $24 \mathrm{~h}$. Whole cell lysates ( $50 \mu \mathrm{g} / \mathrm{lane}$ ) were analysed by Western blotting with IRS-1- and IRS-2-specific antibodies. (B) Quantitative results of insulin dose-dependent decreases in IRS-1 and IRS-2 proteins were expressed as percentages of the decrease of each protein in cells not treated with insulin. Data are presented as means \pm S.E.M. of three independent experiments. (C) After overnight serum starvation, Fao cells were incubated with or without insulin $(100 \mathrm{nmol} / \mathrm{l})$ for the indicated periods. Whole cell proteins (50 $\mu \mathrm{g} /$ lane) or total RNA samples (20 $\mathrm{gg} / \mathrm{lane})$ were subjected to Western blot (IRS-1) or Northern blot (IRS-2) analysis. Data shown are representative of three independent experiments.

anti-IRS-2 antibody respectively. Both IRS proteins showed a dose-response decrease in protein level with a half maximal effect at $8.8 \mathrm{nmol} / 1$ and $13.1 \mathrm{nmol} / 1$ for IRS-1 and IRS-2 respectively (Fig. 1A and B). Both IRS proteins also showed a concentration-dependent decrease in electromobility after insulin treatment with a much larger effect on IRS-2 than on IRS-1 (Fig. 1A).

Figure $1 \mathrm{C}$ shows the time course of the decrease of IRS-1 or IRS-2 protein in Fao cells following treatment with $100 \mathrm{nmol} / 1$ insulin for 2 to $24 \mathrm{~h}$. After $6 \mathrm{~h}$ insulin treatment, the levels of IRS-1 and IRS-2 protein were significantly lower by $\sim 93 \%$ and $\sim 76 \%$ respectively, and this decrease was sustained until $24 \mathrm{~h}$ (Fig. 1C). Again, both IRS-1 and IRS-2 showed a decrease in electromobility. The shift was apparent after $2 \mathrm{~h}$ insulin treatment, continued for $24 \mathrm{~h}$ and was more marked for IRS-2 than for IRS-1. To determine the mechanism responsible for the decrease in IRS proteins, the IRS-1 and IRS-2 mRNA levels were examined after treatment with $100 \mathrm{nmol} / 1$ insulin for $2-24 \mathrm{~h}$ by Northern blot analysis. Consistent with previous studies suggesting that insulininduced down-regulation of IRS-1 protein occurred through its degradation (Araki et al. 1995, Sun et al. 1999, Haruta et al. 2000), the level of IRS-1 mRNA did not show any difference either in the presence or absence of insulin. In contrast, IRS-2 mRNA decreased by 92\% after $2 \mathrm{~h}$ insulin treatment, and this decrease continued until at least $24 \mathrm{~h}$ after insulin treatment.

\section{PI 3-kinase inhibitor blocks the insulin-induced decrease in} IRS-2 $m R N A$ and protein levels

To elucidate the signalling pathway(s) that mediates the insulin-induced decrease in IRS-1 and IRS-2 protein, cells were pretreated with $50 \mu \mathrm{mol} / 1$ PD098059, a MAP Kinase-ERK kinase (MEK) inhibitor that blocks MAP kinase activation, or $50 \mu \mathrm{mol} / 1 \mathrm{LY} 294002$, a specific PI 3-kinase inhibitor, or both for $30 \mathrm{~min}$. The cells were then incubated with or without $100 \mathrm{nmol} / 1$ insulin for $12 \mathrm{~h}$. PD098059 pretreatment did not alter insulin effects on either IRS-1 or IRS-2 protein levels (Fig. 2A). On the other hand, LY294002 pretreatment abrogated the insulin-induced decrease in IRS-1 and IRS-2 protein levels. The same pretreatment also partially, but not 
A

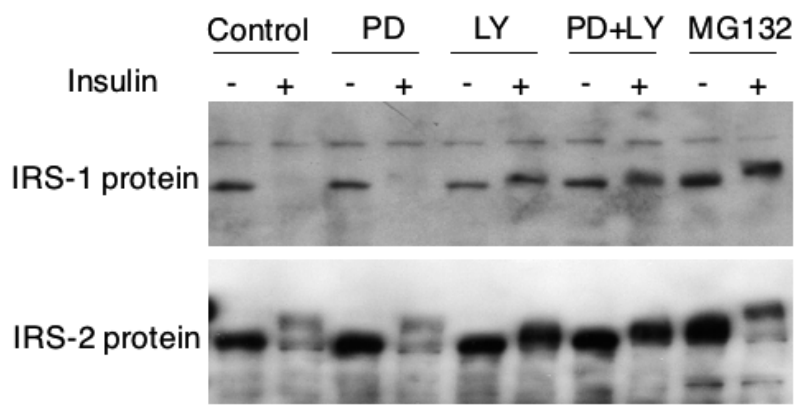

B

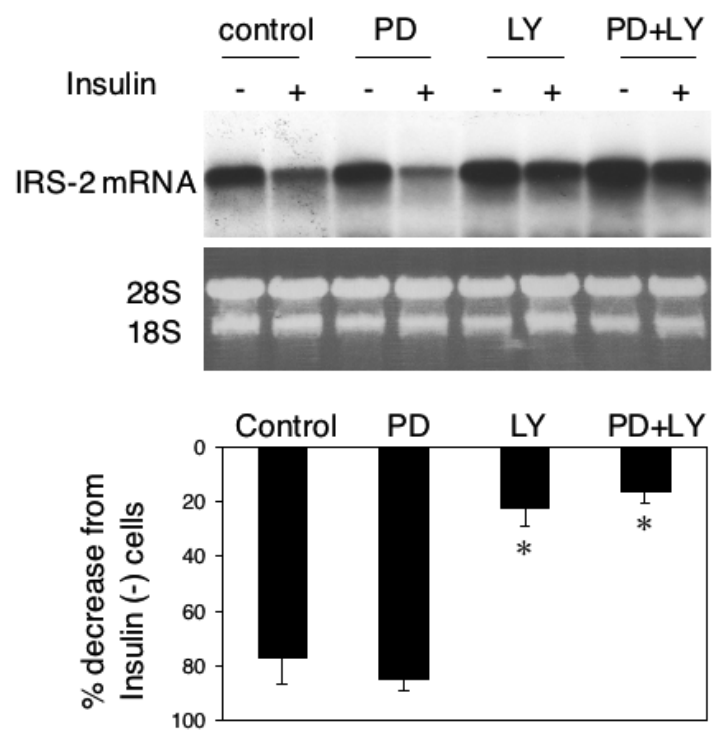

Figure 2 Effects of chemical inhibitors on insulin-induced decreases in IRS-1 and IRS-2. (A) Fao cells were pretreated without or with PD098059 (PD) (50 $\mu \mathrm{mol} / \mathrm{l})$ and/or LY294002 (LY) $(50 \mu \mathrm{mol} / \mathrm{l})$ or MG132 $(50 \mu \mathrm{mol} / \mathrm{l})$ for $30 \mathrm{~min}$ and then incubated with or without insulin $(100 \mathrm{nmol} / \mathrm{l})$ for an additional $12 \mathrm{~h}$. Whole cell lysates were subjected to Western blot analysis of IRS-1 and IRS-2 protein levels. (B) Cells pretreated with PD098059 and/or LY294002 were incubated with or without insulin $(100 \mathrm{nmol} / \mathrm{l})$ for an additional $2 \mathrm{~h}$. Total RNA was subjected to Northern blot analysis of IRS-2 mRNA levels. Ethidium bromide staining of the $18 \mathrm{~S}$ and $28 \mathrm{~S}$ ribosomal RNA confirmed equal loading and integrity of the RNA. Quantitative results of the insulin-induced decrease in IRS-2 mRNA are expressed as percentages of decreases of IRS-2 mRNA levels in cells not treated with insulin in each inhibitor treatment. Data are presented as means \pm S.E.M. of three independent experiments. ${ }^{*} P<0 \cdot 05$.

completely, blocked the insulin-induced decrease in electromobility of the two proteins (Fig. 2A). The combined use of LY294002 and PD98059 compounds had the same effect on blocking the insulin-induced decrease in IRS-1 and IRS-2 proteins. Previous studies have suggested that insulin-induced down-regulation of IRS-1 is mediated via the proteasome-ubiquitin pathway (Sun et al. 1999, Haruta et al. 2000, Lee et al. 2000). In Fao cells MG132, a proteasome inhibitor, almost completely abrogated the insulininduced decrease in IRS-1 protein (Fig. 2A). In contrast, the insulin-induced decrease in IRS-2 protein showed only a minimal change following MG132 treatment.

The effect of the above inhibitors on insulin-induced down-regulation of IRS-2 mRNA was also examined by Northern blot analysis with the cells treated with insulin for $2 \mathrm{~h}$. PD098059 pretreatment had no effect on the insulin-induced decrease in IRS-2 mRNA (Fig. 2B). On the other hand, as seen in IRS-2 protein levels, LY294002 pretreatment significantly inhibited the insulin-induced decrease in IRS-2 mRNA levels (Fig 2B). The effect of chemical inhibitors was further confirmed by the phosphorylation of downstream molecules in insulin signalling. ERK1/2 (p44/p42 MAP kinase) phosphorylation induced by insulin was blocked completely by PD098059 (data not shown). Insulin-induced serine phosphorylation of Akt (also known as protein kinase $\mathrm{B}(\mathrm{PKB})$ ), which is a downstream molecule of the PI 3-kinase pathway, was also significantly but not completely blocked by treatment with the PI 3-kinase inhibitor, LY294002 (data not shown). Interestingly, pretreatment with LY294002 caused a significant increase in ERK1/2 phosphorylation compared with non-pretreated cells, although ERK phosphorylation was not observed in LY294002 and PD98059 pretreatment (data not shown).

\section{Effect of Akt on the insulin-induced decrease in IRS-2} $m R N A$ and protein

Akt has been implicated in the regulation of multiple genes by insulin (Ayala et al. 1999). To examine whether the PI 3-kinase/Akt signal is involved in the regulation of the IRS-2 gene, we inhibited this pathway by overexpression of the dominant-negative form of Akt (DN-Akt) using the adenovirus system. Expression of DN-Akt in the cells partially suppressed the insulin-induced reduction in IRS-2 mRNA levels without any effect on basal levels (Fig. 3A). Overexpression of DN-Akt also completely inhibited the insulin-induced reduction in IRS-2 protein. On the other hand, overexpression of DN-Akt resulted in only a partial attenuation of the insulin-induced decrease in IRS-1 protein (Fig. 3B). Considered together, these results suggest that insulin regulates IRS-2 mRNA and protein levels, at least in part, through the PI 3-kinase/Akt pathway.

Effect of cycloheximide on the insulin-induced decrease in IRS-2 $m R N A$

To determine whether insulin-induced down-regulation of IRS-2 mRNA expression was mediated via synthesis of 


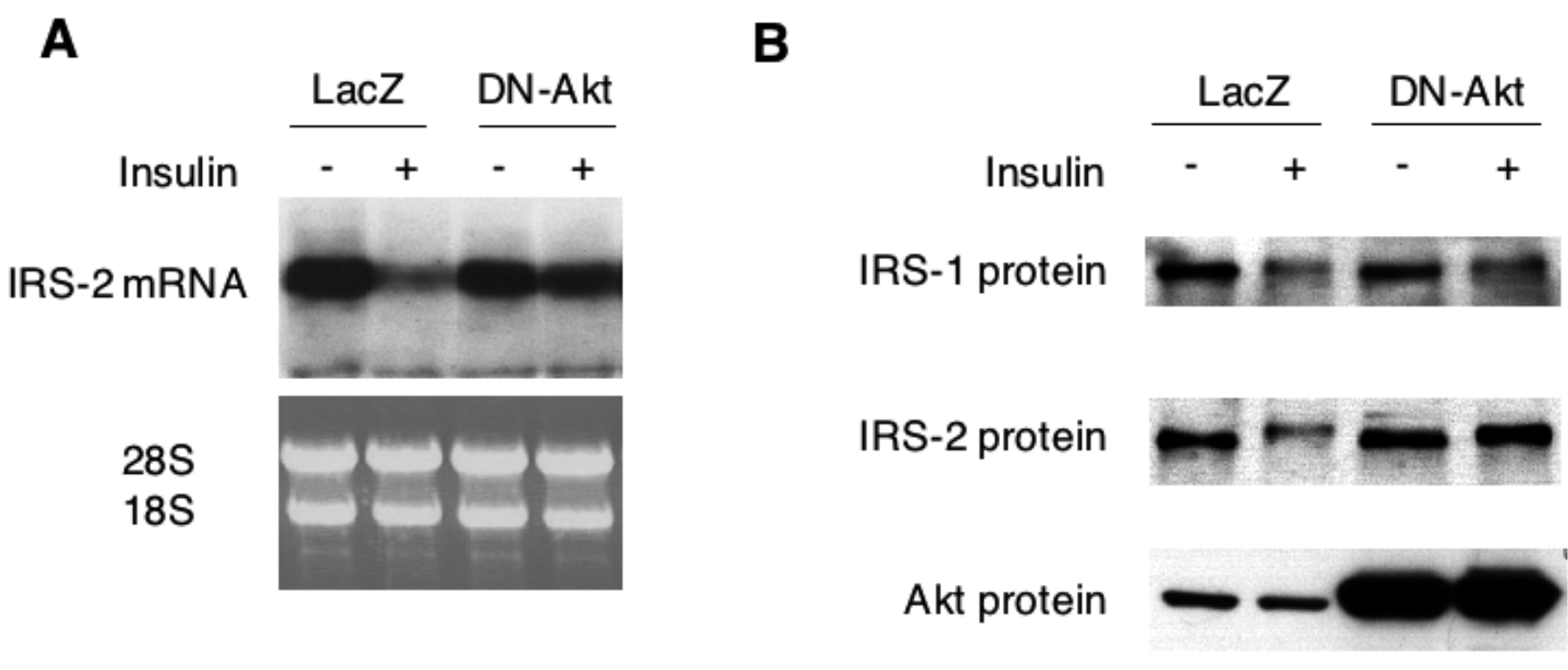

Figure 3 Effect of dominant-negative Akt on IRS-2 mRNA. (A) Confluent Fao cells on $60 \mathrm{~mm}$ dishes were infected with dominant-negative Akt (DN-Akt) or LacZ containing adenovirus at a concentration of $3 \times 10^{8}$ plaque-forming units (PFU). Twenty-four hours after infection, cells were serum-starved overnight and then incubated with or without insulin $(100 \mathrm{nmol} / \mathrm{l})$ for an additional $2 \mathrm{~h}$. Total RNA samples were subjected to Northern blot analysis of IRS-2. Ethidium bromide staining of the $18 \mathrm{~S}$ and $28 \mathrm{~S}$ ribosomal RNA confirmed equal loading and integrity of the RNA. Data shown are representative of three experiments. (B) Fao cells, infected with DN-Akt or LacZ containing adenovirus, were incubated with or without insulin $(100 \mathrm{nmol} / \mathrm{l})$ for $16 \mathrm{~h}$. Whole cell lysates were subjected to Western blot analysis of IRS-1 and IRS-2 protein levels.

other protein(s), Fao cells were pretreated with cycloheximide, a protein synthesis inhibitor, for $30 \mathrm{~min}$ and then incubated with or without insulin for 2 or $6 \mathrm{~h}$ in the presence or absence of cycloheximide. Cycloheximide treatment for $2.5 \mathrm{~h}$ caused a significant increase in IRS-2 mRNA levels in the absence of insulin (Fig. 4A). Twohour insulin stimulation reduced IRS-2 mRNA levels by $40 \%$ in the presence of cycloheximide, and this reduction was significantly smaller than in untreated cells. After $6 \mathrm{~h}$, IRS-2 mRNA levels in cells treated with cycloheximide alone were comparable with those in control cells without insulin (Fig. 4B). Importantly, a decrease in IRS-2 mRNA by $6 \mathrm{~h}$ insulin treatment was diminished completely in the presence of cycloheximide.

\section{Insulin has no effect on the half-life of IRS-2 $m R N A$}

Insulin could affect mRNA levels by altering the rate of gene transcription or by changing the stability of mRNA (O’Brien \& Granner 1996). Using reporter gene analysis, Zhang et al. (2001) indicated that insulin suppressed transcription of the IRS-2 gene. To examine the effect of insulin on the half-life $\left(t_{1 / 2}\right)$ of mRNA, Fao cells were pretreated with $5 \mu \mathrm{g} / \mathrm{ml}$ actinomycin $\mathrm{D}$, an inhibitor of RNA synthesis, for $15 \mathrm{~min}$ and were then incubated with or without insulin for 0-90 $\mathrm{min}$ in the presence of actinomycin D. In the presence of actinomycin D, the $t_{1 / 2}$ of IRS-1 and IRS-2 mRNAs in control cells were $26 \pm 5.2 \mathrm{~min}$ and $59 \pm 6.3 \mathrm{~min}$ respectively (data not shown). Importantly, insulin treatment did not alter the $t_{1 / 2}$ of IRS- 1 and IRS-2 mRNAs. These results, together with those of previous studies (Zhang et al. 2001, Iwamoto et al. 2002), suggest that insulin decreases IRS-2 mRNA levels by reducing the rate of transcription of the IRS-2 gene.

Binding of nuclear proteins with the insulin response element-like sequence on the IRS-2 gene is PI 3-kinase dependent

Previous studies have shown that the insulin response element (IRE)-like sequence is found in both human (TGTTTTG at -574 to -568 ) and mouse (TGTTTTG at -1571 to -1565$)$ IRS-2 gene promoters, and that the IRE on human IRS-2 is involved in the regulation of its transcription by insulin (Zhang et al. 2001, Iwamoto et al. 2002). To clarify if the effect of insulin on IRS-2 mRNA is PI-3 kinase-dependent, we examined the association of the IRE motif (nt -585 to -557 ) in the IRS-2 promoter with nuclear proteins prepared from insulin-stimulated Fao cells by EMSA. The interaction of IRE and nuclear proteins was increased at $2 \mathrm{~h}$ after insulin stimulation, and the increase in IRE-nuclear protein complexes continued for at least $6 \mathrm{~h}$ (Fig. 5A). The addition of excessive amounts of unlabelled IRE motif (nt -585 to -557 ) effectively inhibited the formation of the IRE-nuclear protein complex. Inhibition of PI 3-kinase by LY294002 resulted in suppression of the increase of the IRE-nuclear protein interaction, but PD98059 failed to produce the same results. Moreover, cycloheximide partially impaired the increase in nuclear proteins and IRE binding (Fig. 5B). 
A
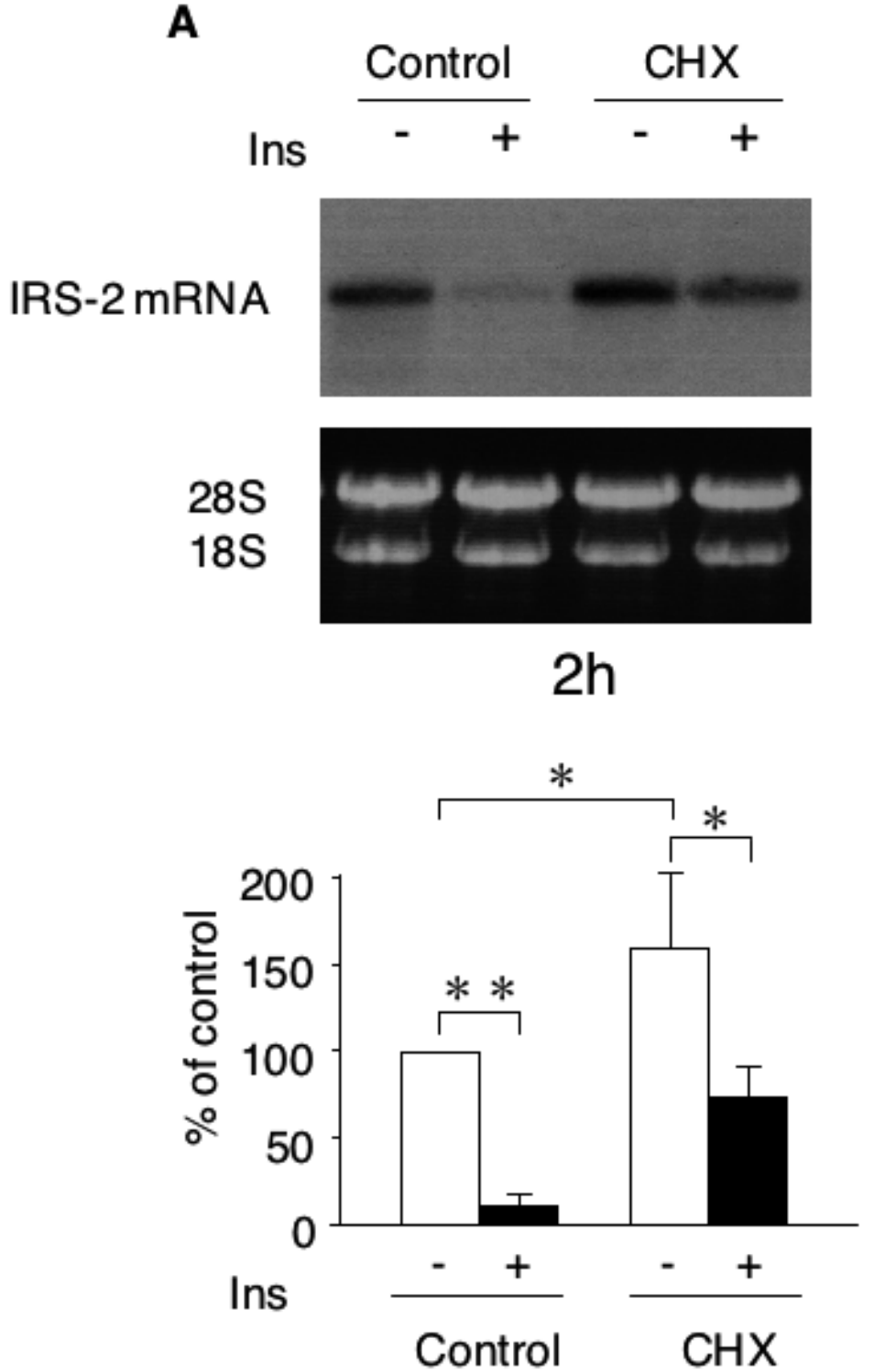

B
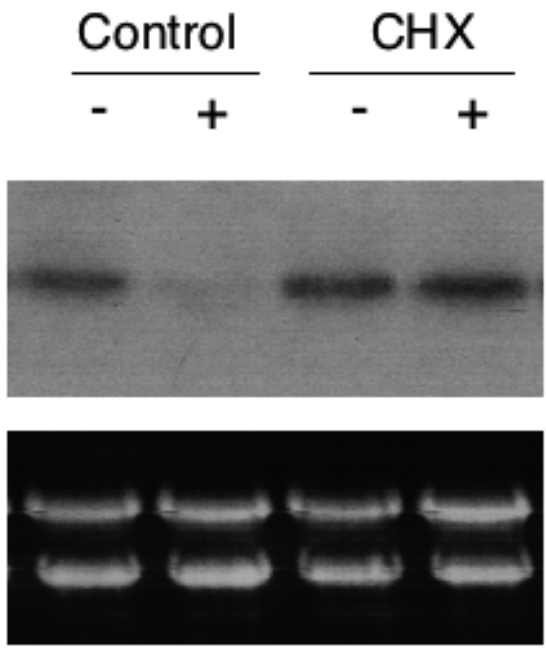

$6 \mathrm{~h}$

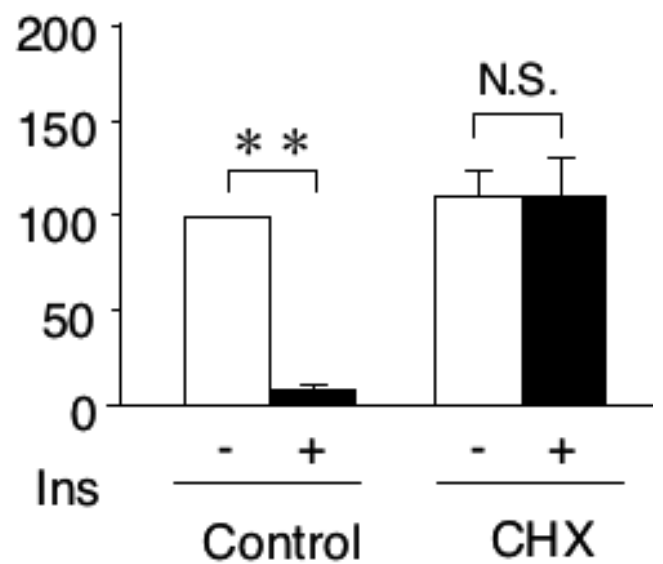

Figure 4 Effects of cycloheximide (CHX), a protein synthesis inhibitor, on insulin-induced suppression of IRS-2 mRNA. Fao cells were pretreated without or with $\mathrm{CHX}(5 \mu \mathrm{g} / \mathrm{ml})$ for $30 \mathrm{~min}$ and then incubated with insulin $(100 \mathrm{nmol} / \mathrm{l})$ for 2 (A) or 6 (B) h. Total RNA samples were subjected to Northern blot analysis of IRS-2 mRNA. Ethidium bromide staining of the $18 \mathrm{~S}$ and $28 \mathrm{~S}$ ribosomal RNA confirmed equal loading and integrity of the RNA. The lower panels show the quantitative results of IRS-2 mRNA levels. Data, expressed as percentages of IRS-2 mRNA in cells not treated with insulin and $\mathrm{CHX}$, are presented as means \pm S.E.M. of three independent experiments. ${ }^{*} P<0 \cdot 05$, $* * P<0 \cdot 01$.

These results indicated that insulin-induced PI 3-kinase activation was involved in binding of nuclear proteins to the IRE motif, and the effect of insulin was mediated, at least in part, via synthesis of some proteins.

Insulin-induced suppression of IRS-2 gene promoter activity is mediated via PI 3-kinase

To confirm the role of PI 3-kinase pathway in insulininduced suppression of IRS-2 gene transcription, luciferase reporter plasmids carrying various lengths of the human IRS-2 gene promoter, pGL3-IRS2 (-834), pGL3-IRS2 ( - 1824) and pGL3-IRS2 (-2116), were transiently introduced into Fao cells. Insulin suppressed luciferase activity of pGL3-IRS2 $(-2116)$ by $68 \%$ $(P<0 \cdot 05) \quad$ compared with that of non-insulintreated cells (Fig. 6). Cells transfected with pGL3-IRS2 $(-1824)$ or pGL3-IRS2 $(-834)$ also showed marked reduction of luciferase activity in the presence of insulin (by $59 \%(P<0 \cdot 05)$ and $55 \%(P<0 \cdot 05)$ respectively). 
A

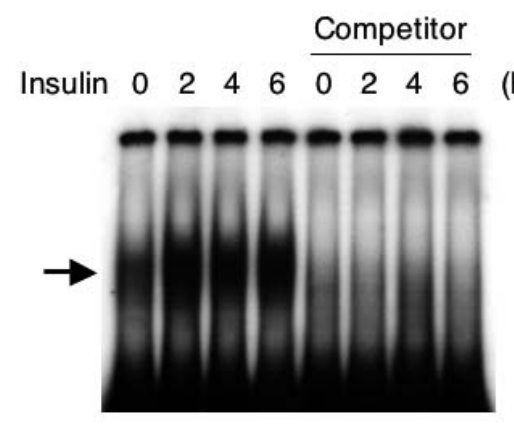

B

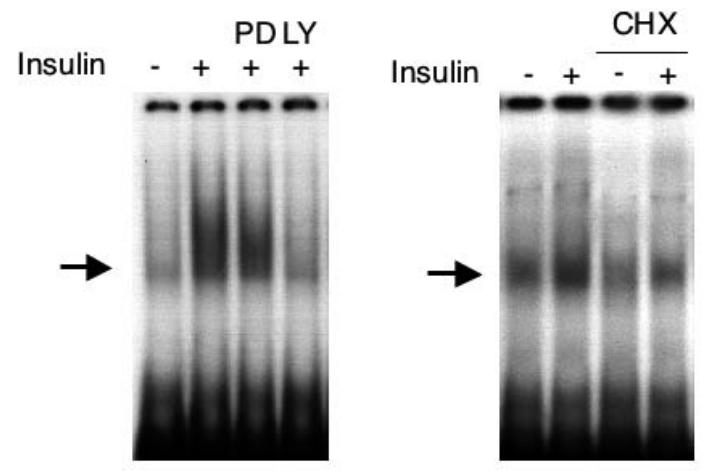

Figure 5 EMSA for insulin response element-like sequence on IRS-2 gene promoter. (A) Serum-starved Fao cells were cultured with or without insulin $(100 \mathrm{nmol} / \mathrm{l})$ for the indicated time periods. Nuclear protein was incubated with ${ }^{32} \mathrm{P}$-labelled insulin response element (IRE)-like sequence in the human IRS-2 gene promoter (nt -585 to -557 ) in the absence or presence of cold competitor as described in Materials and Methods. Incubated samples were separated on polyacrylamide gels and visualized by autoradiography. The arrow indicates the nuclear protein-probe complexes. (B) Serum-starved Fao cells were pre treated with LY294002 (50 $\mu \mathrm{mol} / \mathrm{l})$ or cycloheximide $(\mathrm{CHX}, 5 \mu \mathrm{g} / \mathrm{ml})$ for $30 \mathrm{~min}$ and then stimulated with insulin $(100 \mathrm{nmol} / \mathrm{l})$ for $6 \mathrm{~h}$. Nuclear protein was subjected to EMSA for IRE-like sequence as described above. Arrows indicate the nuclear protein-probe complexes.

Pretreatment with LY294002 caused a slight but significant reduction in luciferase activity in pGL3-IRS2 $(-834)$ and pGL3-IRS2 (-2116). Luciferase activity in insulin-stimulated cells in the presence of LY294002 was significantly higher than in the absence of LY294002 (by $95 \%, 69 \%$ and $68 \%$ in cells transfected with pGL3-IRS2 $(-2116), \quad$ pGL3-IRS2 $(-1824)$ and pGL3-IRS2 $(-834)$ respectively. $P<0 \cdot 05)$. Importantly, there was no significant difference in luciferase activity between cells treated with LY294002 alone and those treated with LY294002 plus insulin in any of the cell lines. These results suggested that inhibition of PI 3-kinase by LY294002 was sufficient to abrogate the insulin-induced decrease in IRS-2 promoter activity.

Although the IRE-like sequence on the human IRS-2 gene, TGTTTTG located at position -574 to -568 , and its surrounding sequence is not conserved in the

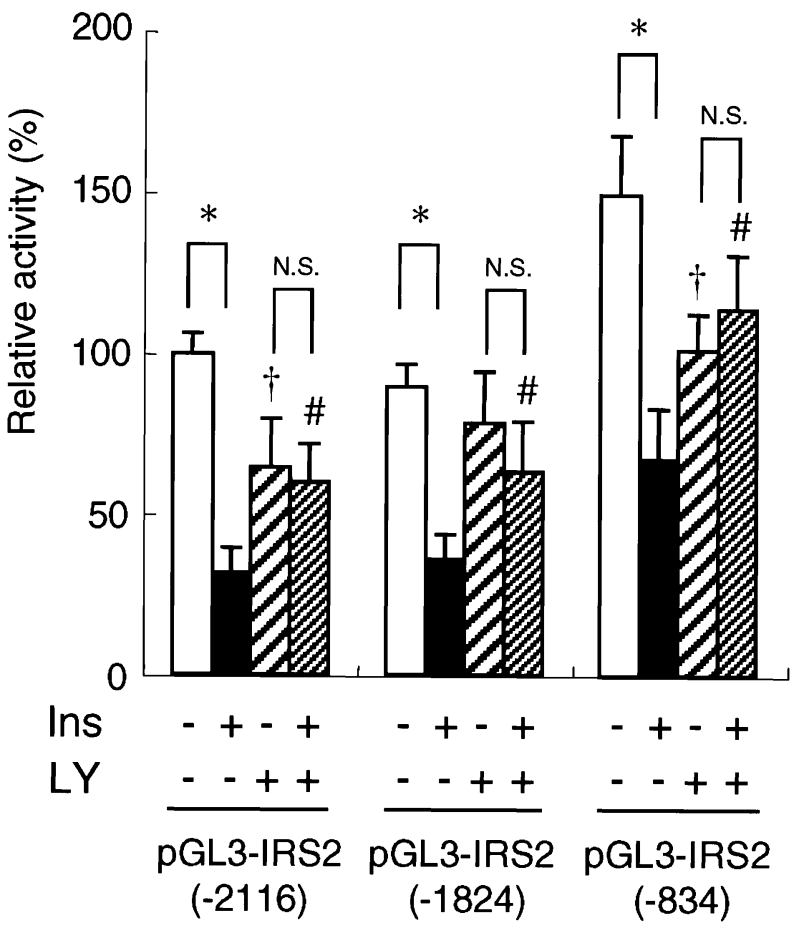

Figure 6 Effects of insulin on the human IRS-2 gene promoter activity. The reporter plasmids (the human IRS-2 gene promoter fragment beginning at position $-2116,-1824$, or -834 and terminating at position -124 as inserted into pGL3-Basic) were transiently introduced into Fao cells. After 6-h serum starvation, cells were pretreated without or with LY294002 (50 $\mu \mathrm{mol} / \mathrm{l})$ for $30 \mathrm{~min}$ and then incubated with or without insulin $(100 \mathrm{nmol} / \mathrm{l})$ for an additional $12 \mathrm{~h}$. The normalized firefly luciferase activity of cell lysates transfected with pGL3-IRS2 ( -834$)$, pGL3-IRS2 $(-1824)$ and pGL3-IRS2 $(-2116)$ was measured as described in Materials and Methods, and expressed relative to that of pGL3-IRS2 $(-2116)$ in the absence of insulin. Data are mean \pm S.E.M. values of six independent experiments. $\# P<0.05$ vs $\mathrm{LY}(-) \operatorname{Ins}(+)$ of each plasmid, $+P<0.05$ vs $\operatorname{LY}(-) \operatorname{lns}(-)$ of each plasmid, ${ }^{*} P<0 \cdot 05$. N.S., not significant.

mouse IRS-2 gene, an IRE sequence of TGTTTTG is located at position -1571 to -1565 on the mouse IRS-2 gene (Zhang et al. 2001). To examine the possible presence of a motif corresponding to this IRE sequence on the rat IRS-2 gene promoter, we cloned the partial rat IRS-2 gene promoter by PCR amplification using primers designed against mouse DNA sequence. We could amplify the $396 \mathrm{bp}$ partial promoter sequence from the genome DNA of Fao cells and Wistar rats. There was no difference in the nucleotide sequence of this partial promoter region between Fao cells and Wistar rats. Alignment of the DNA sequences of IRS-2 promoter of rat, mouse and human was investigated (Fig. 7A). The nucleotide sequences of this area have high homology among rat, mouse, and human. The TGTTTTG sequence corresponding to the IRE is found in this area, and is highly conserved among rat (nucleotide position is unknown), mouse ( -1571 to -1565$)$ and 
A

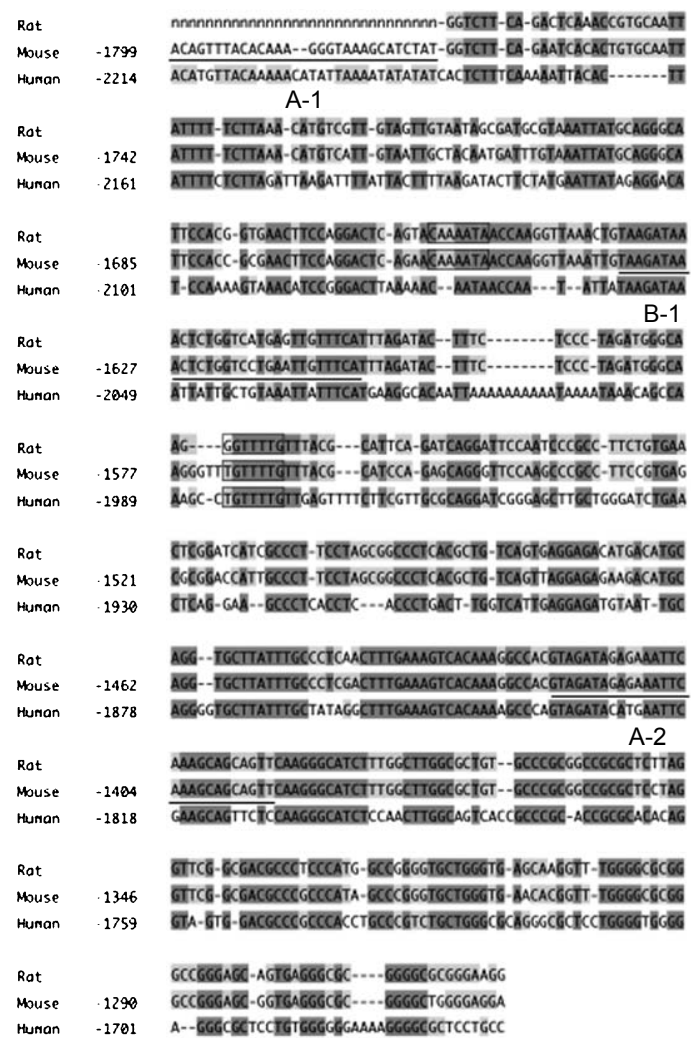

B

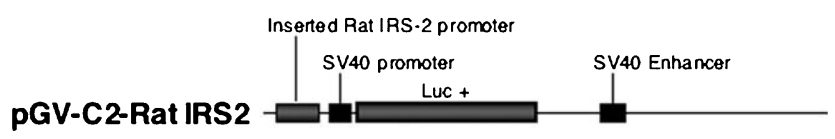

C

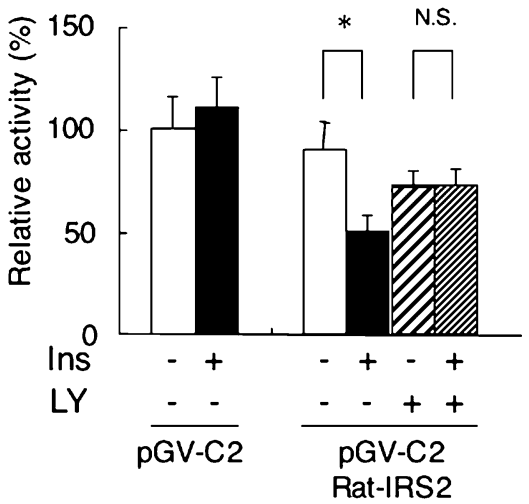

Figure 7 Effect of insulin on the rat IRS-2 gene promoter activity. (A) Alignment of the DNA sequences of rat, mouse, and human IRS-2 gene promoters. Shaded letters show the conserved nucleotides across two (grey) or three (dark grey) species. A-1, A-2 and B-1 represent the position of PCR primers used for cloning of the rat IRS-2 gene promoter. Another PCR primer, B-2, is located at 60 bp downstream of this illustrated sequence. The enclosed TGTTTTG, GGTTTTG and CAAAATA are insulin response element (IRE)-like sequences. (B) Schematic structure of pGV-C2-Rat IRS2. The $\sim 396$ bp rat DNA fragment obtained by PCR amplification with primers A-1 and A-2 was inserted into pGV-C2 (pGV-C2-Rat IRS2). (C) Normalized firefly luciferase activity of cell lysates transfected with pGV-C2 or pGV-C2-Rat IRS2 under the indicated conditions was measured and expressed relative to that of pGV-C2 in the absence of insulin. Data are mean \pm S.E.M. values of six independent experiments and two independent transfections. ${ }^{*} P<0 \cdot 05$. N.S., not significant.

human ( -1984 to -1978$)$ with a single nucleotide substitution in the rat genome GGTTTTG. There is another IRE-like sequence CAAAATA near the TGTTTTG motif and it is conserved between rat (nucleotide position is unknown) and mouse ( -1657 to -1650) (Fig. 7A). To examine if the rat DNA sequence including these CAAAATA and GGTTTTG motifs exhibited insulin responsiveness, we created a pGV-C2-Rat IRS2 plasmid, in which a partial rat IRS-2 gene promoter was inserted just before the SV40 promoter (Fig. 7B). The pGV-C2-Rat IRS2 or its parental plasmid, pGV-C2, was transfected into Fao cells (Fig. 7C). The pGV-C2 showed no response to insulin stimulation. However, insulin stimulation resulted in about 44\% suppression of the promoter activity of pGV-C2-Rat IRS2 $(P<0 \cdot 05)$, while pre treatment with LY294002 prevented such insulin-induced suppression of pGV-B2-Rat IRS2 promoter activity (Fig. 7C).

\section{Discussion}

The IRS family of proteins represents the major intracellular substrates for insulin and insulin-like growth factor-I (IGF-I) receptor tyrosine kinases (White 1998). Among the IRS family members, both IRS-1 and IRS-2 have been shown to play crucial roles in glucose homeostasis and physical development (Araki et al. 1994, Tamemoto et al. 1994, Withers et al. 1998). Both IRS-1 and IRS-2 proteins are expressed in most tissues (Araki et al. 1993, Sun et al. 1995), and the expression level of these proteins is altered in abnormal states, such as insulin resistance or diabetes in humans (Goodyear et al. 1995, Rondinone et al. 1997, Friedman et al. 1999). In the liver, IRS-2 appears to be more important than IRS-1 in mediating insulin signalling, whereas in skeletal muscles, the IRS-1 is more important than IRS-2 (Araki et al. 1994, Yamauchi et al. 1996). Although several studies 
have investigated the regulation of IRS-1 protein, the mechanisms that regulate IRS-2 protein expression are largely unknown. Both ob/ob mice and Zucker fatty rats, animal models of hyperinsulinaemia, have low IRS-1 and IRS-2 protein in the liver (Saad et al. 1992, Kerouz et al. 1997, Anai et al. 1998, Shimomura et al. 2000). In contrast, hypoinsulinaemia in streptozotocin (STZ) diabetic rats causes increased expression of IRS-1 and IRS-2 proteins in the liver (Saad et al. 1992, Shimomura et al. 2000). We have found recently that disruption of insulin signalling in the liver-specific knockout of the insulin receptor (LIRKO) mouse leads to a marked increase in IRS-2 protein in this tissue (Michael et al. 2000). These findings suggest that insulin itself regulates both IRS-1 and IRS-2 protein levels in the liver. In the present study, we found that these insulin effects are mediated via different mechanisms, and that insulin causes a decrease in both mRNA and protein levels of IRS-2 in Fao cells. Our results suggest that insulin-induced reduction of IRS-2 mRNA is probably due to the inhibition of IRS-2 gene transcription and is mediated through the PI 3-kinase/Akt pathway.

Insulin reduced IRS-1 protein levels in Fao cells without any significant change in its mRNA levels. This is similar to the effect of insulin on IRS-1 protein in 3T3-F442A and 3T3-L1 adipocytes (Rice et al. 1993, Araki et al. 1995). In these cells, this insulin effect was associated with a significant shortening of the half-life of IRS-1 protein. Recent studies have shown that insulin (and IGF-I) enhances the degradation of IRS-1 protein through a proteasomal degradation pathway in several cell types (Sun et al. 1999, Haruta et al. 2000, Lee et al. 2000). This insulin-induced increase in IRS-1 protein degradation is blocked by inhibition of the PI 3-kinase pathway. The present data indicate that this pathway is also operational in the liver, where insulin-induced suppression of IRS-1 protein is mediated by proteasomal degradation and is regulated via the PI 3-kinase pathway.

In contrast to IRS-1, treatment of Fao cells with insulin resulted in significant reductions in both IRS-2 mRNA and protein levels. Interestingly, our results showed that the effect of insulin on IRS-2 mRNA occurred earlier (within $2 \mathrm{~h}$ ) than on the protein level $(6 \mathrm{~h})$. Although the proteasome inhibitor, MG132, had a minimal effect on insulin action on IRS-2 protein in the present study, Rui et al. (2001) have shown that the decrease in IRS-2 protein levels as a result of insulin treatment was partially blocked by pretreatment of fibroblasts and Fao cells with another proteasome inhibitor. Considered together, the results of our study and those of the above group suggest that insulin could reduce IRS-2 protein levels through two unique mechanisms: suppression of IRS-2 mRNA expression and acceleration of degradation of IRS-2 protein.

Our results also showed that the PI 3-kinase inhibitor, LY294002, but not the MEK inhibitor, PD098059, blocked insulin-induced suppression of both IRS-2 protein and mRNA. Furthermore, LY294002 almost completely inhibited the insulin-induced decrease in IRS-2 at the protein level, whereas its effect on the decrease in mRNA levels was significant although not complete. This again may suggest that IRS-2 protein levels may be controlled by insulin through mechanisms operational at both the protein and mRNA levels. The incomplete blocking of insulin-induced suppression of IRS-2 mRNA by LY294002 might be due to incomplete inhibition of this pathway, since downstream Akt phosphorylation was markedly reduced by this inhibitor, but was not completely blocked. However, it is also possible that a PI 3-kinase-independent pathway also contributes to the insulin-induced decrease in IRS-2 mRNA. LY294002 treatment caused enhanced ERK1/2 phosphorylation in our experiments, suggesting a signalling cross-talk between the PI 3-kinase pathway and the MAP kinase pathway in this cell line (Rommel et al. 1999, Zimmermann \& Moelling 1999). However, it is unlikely that the effect of LY294002 on IRS-2 mRNA levels was mediated by MAP kinase activation, since both the PI 3-kinase and the MEK inhibitor also blocked the insulininduced suppression of IRS-2 mRNA similar to the effect of LY294002 alone.

Akt is an immediate downstream effector of PI 3-kinase and mediates several of the biological actions of insulin such as glucose uptake (Kohn et al. 1996), glycogen synthesis (Ueki et al. 1998), lipid metabolism (Degerman et al. 1997, Kitamura et al. 1999) and gene expression (Cichy et al. 1998). In the experiments using the adenovirus system, we demonstrated that the dominant-negative Akt partially blocked the insulin-induced decrease in IRS-2 mRNA, suggesting that Akt is involved in the regulation of IRS-2 mRNA expression.

Actinomycin D prevents the synthesis of RNA and, therefore, it allows examination of the stability of RNAs that have already been synthesized. In our studies using actinomycin D, we found that the half-life of IRS-2 mRNA (24 $\pm 5 \cdot 2 \mathrm{~min})$ in Fao cells was much shorter than that of IRS-1 mRNA (59 $\pm 6 \cdot 3 \mathrm{~min})$ and it was not affected by insulin treatment. We have previously reported the $t_{1 / 2}$ of IRS-1 mRNA in 3T3-F442A cells $(190 \pm 28 \mathrm{~min})$ (Araki et al. 1995). The differences in the half-life of IRS-1 mRNA between Fao cells and 3T3F442A cells suggest that the stability of IRS-1 mRNA may vary in different tissues. More importantly, insulin did not change the rate of decrease of either IRS-1 or IRS-2 mRNAs.

It is well known that insulin regulates the expression of several genes by regulating gene transcription or mRNA stability (O'Brien \& Granner 1996). Since the suppression of IRS-2 mRNA by insulin in Fao cells is not due to the enhancement of the degradation of IRS-2 mRNA, insulin must modulate the transcription of the IRS-2 gene. Indeed Zhang et al. (2001) have reported that insulin suppressed the transcription of the IRS-2 gene by reporter gene analysis. Insulin has been shown to regulate gene 
expression by acting through IREs (O'Brien \& Granner 1996). The best described of these elements is an IRE with a T(G/A)TTT(T/G)(G/T) core sequence (Hall et al. 2000). The nucleotide sequences of the $5^{\prime}$ non-coding regions of the IRS-2 genes of human and mouse have been published in part, although the sequence in the rat species is not known (Sun et al. 1997, Vassen et al. 1999). The IRE core sequence is found in both human (TGTTTTG at -574 to -568 ) and mouse (TGTTTTG; see refs in Zhang et al. 2001) IRS- 2 gene promoter. This IRE on the human IRS-2 gene is involved in the regulation of its transcription by insulin (Zhang et al. 2001). In the present study, we found that nuclear proteins from Fao cells associated with the IRE fragment of the human IRS-2 gene in vitro. The association was completely blocked by the addition of an excessive amount of cold probes, confirming that the association is specific. The nuclear protein-probe complex was already visible in the basal state and, interestingly, the association was enhanced in nuclear extracts prepared from insulin-treated cells. More importantly, as LY294002 blocked the insulininduced reduction in IRS-2 mRNA expression, the LY compound significantly attenuated the insulin-induced increase in the association of nuclear protein with the IRE probe. These results suggest the existence in Fao cells of a nuclear protein that could bind to the IRE sequence in IRS-2 gene. The affinity of the nuclear protein with the IRE sequence and/or the amount of the nuclear protein would be regulated by insulin via a PI 3-kinase pathway.

In the promoter analysis using reporter plasmids, insulin clearly suppressed the transcriptional activity of the human IRS-2 gene promoter. In this experiment, we used three types of reporter plasmids that contain several lengths of the IRS-2 gene promoter. Although the longest plasmid, pGL3-IRS2 ( -2116$)$, contains two IRE-like sequences $(-574$ to -568 and -1984 to -1978$)$ while the others contain only one IRE ( -574 to -568 ), the magnitude of the insulin-induced reduction in luciferase activity was similar in the three reporter plasmids. This might mean that the IRE $(-574$ to -568$)$ is essential for insulin responsiveness of the human IRS-2 gene. In reporter gene analysis, LY294002 pretreatment caused a slight but significant reduction in luciferase activity in the absence of insulin. Although LY294002 could reduce basal promoter activity in the luciferase assay, LY294002 had no effect on basal IRS-2 mRNA levels shown in Northern blotting (Fig. 2B). The underlying mechanism of these effects is unclear at present. The luciferase assay reflects the amount of synthesized luciferase proteins, thus the results would not be completely identical with the results from Northern blotting which reflects the amount of mRNA. It may be possible that basal PI 3-kinase activity, which is activated by substances other than insulin, has some effect on the synthesis or stability of luciferase. We found that luciferase activity in insulin-stimulated cells in the presence of
LY294002 was significantly elevated relative to that in the absence of LY294002. Importantly, there was no difference in luciferase activity between cells treated with LY294002 alone and LY294002 plus insulin. These results also support the notion that inhibition of PI 3-kinase by LY294002 was sufficient to prevent the insulin-induced decrease in IRS-2 expression.

Since Fao cells are a rat cell line, we confirmed that the rat IRS-2 gene promoter shows insulin responsiveness. For this purpose, we cloned partial rat DNA sequence and identified an IRE-like sequence corresponding to the IRE in the mouse IRS-2 gene (Zhang et al. 2001). The nucleotide sequence surrounding this IRE has high homology with mouse and human IRS-2 genes. There is another IRE-like sequence (CAAAATA) about $80 \mathrm{bp}$ upstream of the TGTTTTG motif and it is conserved in the rat and mouse. The reporter plasmid pGV-C2-Rat IRS2, containing the partial rat IRS-2 gene promoter, has acquired insulin-responsiveness compared with its parental plasmid, pGV-C2, suggesting that insulin suppresses the rat IRS-2 gene transcription probably through this region that includes IRE-like sequences.

The identity of the nuclear protein(s) that binds to the IRE sequence of the IRS-2 gene is currently unknown. It has been shown that forkhead rhabdomyosarcoma transcription factor (FKHR) could bind to the IRE sequence of other insulin-responsive genes and is involved in the regulation of IGF-binding protein-1 gene expression by PI 3-kinase-mediated insulin signal (Guo et al. 1999). In a preliminary experiment, we found that a specific antibody for FKHR could reduce nuclear proteinIRE complexes in EMSA analysis, although a supershift of the band was not noted. Further studies using the IRS-2 gene promoter should help clarify the role of the IREassociated nuclear proteins, including FKHR, in the regulation of IRS-2 gene transcription.

Our results also showed that cycloheximide, a protein synthesis inhibitor, blocked the insulin-induced reduction in IRS-2 mRNA, especially when the incubation period was long. This effect strongly suggests that this reduction, at least at a later time point, is mediated via a newly synthesized protein factor(s). Cycloheximide also attenuated the insulin-increased nuclear protein-IRE complexes in EMSA analysis. In general, binding of transcription factors with the cis-acting elements of the promoter sequence is up-regulated by increasing the amounts of such factors, translocation of the factors into the nucleus, and/or increasing their binding affinities (Orphanides et al. 1996, Roeder 1996). Thus, although our results do not simply mean that insulin stimulates the synthesis of nuclear proteins that bind to the IRE sequence, newly synthesized protein(s) by insulin stimulation should be necessary for the processes of protein-IRE interaction. It should also be noted that cycloheximide failed to block the insulininduced reduction in IRS-2 mRNA levels over a short incubation period. This may suggest that insulin can 
regulate IRS-2 mRNA levels independent with the synthesis of the protein factor(s) in earlier periods.

Recently Pirola et al. (2003) have shown that insulininduced desensitization of insulin signalling in L6 myoblasts was correlated to a reduction in IRS-1 and IRS-2 protein levels, which was reversed by the PI 3-kinase inhibitor, LY294002. Together with this report and our current results, PI 3-kinase has been shown to be the chief molecule controlling insulin-induced down-regulation of IRS-1 and IRS-2 not only in the skeletal muscle but also in the liver.

In summary, the present study showed that insulin treatment reduced IRS-2 mRNA and protein levels in hepatocytes. Such a decrease was likely due to the repression of IRS-2 gene transcription by insulin via a process mediated by the PI 3-kinase/Akt pathway and by some nuclear proteins binding to the IRE sequence on the IRS-2 gene. These new findings should help clarify the role of IRS-2 protein and insulin resistance in the liver.

\section{Acknowledgements}

We are grateful to Dr M Hashiramoto and K Iwamoto (Kobe University, Kobe, Japan) for providing the luciferase reporter plasmids, pGL3-IRS2 (-834), pGL3IRS2 (-1824) and pGL3-IRS2 (-2116). We thank members of the Gene Technology Center (Kumamoto University, Kumamoto, Japan) for their important contribution to the experiments, A Shirakami, J Kawashima, $\mathrm{K}$ Sakai, $\mathrm{T}$ Matsuo, $\mathrm{T}$ Matsumura and $\mathrm{K}$ Ichinose (Kumamoto University, Kumamoto, Japan) for providing valuable suggestions during the experiments, and $\mathrm{M}$ Takahashi (Kumamoto University, Kumamoto, Japan) for her assistance with sequence analyses.

\section{Funding}

This work was supported by a Grant-in-Aid for Scientific Research from the Japan Society for the Promotion of Science, Japan (to E A) (no. 12671117).

\section{References}

Anai M, Funaki M, Ogihara T, Terasaki J, Inukai K, Katagiri $\mathrm{H}$, Fukushima Y, Yazaki Y, Kikuchi M, Oka Y et al. 1998 Altered expression levels and impaired steps in the pathway to phosphatidylinositol 3-kinase activation via insulin receptor substrates 1 and 2 in Zucker fatty rats. Diabetes 47 13-23.

Araki E, Sun XJ, Haag BL 3rd, Chuang LM, Zhang Y, Yang-Feng TL, White MF \& Kahn CR 1993 Human skeletal muscle insulin receptor substrate-1. Characterization of the cDNA, gene, and chromosomal localization. Diabetes 42 1041-1054.

Araki E, Lipes MA, Patti ME, Bruning JC, Haag B 3rd, Johnson RS \& Kahn CR 1994 Alternative pathway of insulin signalling in mice with targeted disruption of the IRS-1 gene. Nature 372 186-190.
Araki E, Haag BL 3rd, Matsuda K, Shichiri M \& Kahn CR 1995 Characterization and regulation of the mouse insulin receptor substrate gene promoter. Molecular Endocrinology 9 1367-1379.

Ayala JE, Streeper RS, Desgrosellier JS, Durham SK, Suwanichkul A, Svitek CA, Goldman JK, Barr FG, Powell DR \& O’Brien RM 1999 Conservation of an insulin response unit between mouse and human glucose-6-phosphatase catalytic subunit gene promoters: transcription factor FKHR binds the insulin response sequence. Diabetes 48 1885-1889.

Bradford MM 1976 A rapid and sensitive method for the quantitation of microgram quantities of protein utilizing the principle of protein-dye binding. Analytical Biochemistry 72 248-254.

Bruning JC, Winnay J, Bonner-Weir S, Taylor SI, Accili D \& Kahn CR 1997 Development of a novel polygenic model of NIDDM in mice heterozygous for IR and IRS-1 null alleles. Cell 88 561-572.

Cheatham B, Vlahos CJ, Cheatham L, Wang L, Blenis J \& Kahn CR 1994 Phosphatidylinositol 3-kinase activation is required for insulin stimulation of pp70 S6 kinase, DNA synthesis, and glucose transporter translocation. Molecular and Cellular Biology 14 4902-4911.

Cichy SB, Uddin S, Danilkovich A, Guo S, Klippel A \& Unterman TG 1998 Protein kinase B/Akt mediates effects of insulin on hepatic insulin-like growth factor-binding protein-1 gene expression through a conserved insulin response sequence. Journal of Biological Chemistry 273 6482-6487.

DeFronzo RA 1997 Insulin resistance: a multifaceted syndrome responsible for NIDDM, obesity, hypertension, dyslipidaemia and atherosclerosis. Netherlands Journal of Medicine 50 191-197.

Degerman E, Belfrage P \& Manganiello VC 1997 Structure, localization, and regulation of cGMP-inhibited phosphodiesterase (PDE3). Journal of Biological Chemistry 272 6823-6826.

Dorrestijn J, Ouwens DM, Van den Berghe N, Bos JL \& Maassen JA 1996 Expression of a dominant-negative Ras mutant does not affect stimulation of glucose uptake and glycogen synthesis by insulin. Diabetologia 39 558-563.

Friedman JE, Ishizuka T, Shao J, Huston L, Highman T \& Catalano P 1999 Impaired glucose transport and insulin receptor tyrosine phosphorylation in skeletal muscle from obese women with gestational diabetes. Diabetes 48 1807-1814.

Furukawa N, Shirotani T, Araki E, Kaneko K, Todaka M, Matsumoto K, Tsuruzoe K, Motoshima H, Yoshizato K, Kishikawa H et al. 1999 Possible involvement of atypical protein kinase C (PKC) in glucose-sensitive expression of the human insulin gene: DNAbinding activity and transcriptional activity of pancreatic and duodenal homeobox gene-1 (PDX-1) are enhanced via calphostin C-sensitive but phorbol 12-myristate 13-acetate (PMA) and Go 6976-insensitive pathway. Endocrine Journal 46 43-58.

Gerfen CR, Keefe KA \& Gauda EB 1995 D1 and D2 dopamine receptor function in the striatum: coactivation of D1- and D2-dopamine receptors on separate populations of neurons results in potentiated immediate early gene response in D1-containing neurons. Journal of Neuroscience 15 8167-8176.

Goodyear LJ, Giorgino F, Sherman LA, Carey J, Smith RJ \& Dohm GL 1995 Insulin receptor phosphorylation, insulin receptor substrate-1 phosphorylation, and phosphatidylinositol 3-kinase activity are decreased in intact skeletal muscle strips from obese subjects. Journal of Clinical Investigation 95 2195-2204.

Gorski K, Carneiro M \& Schibler U 1986 Tissue-specific in vitro transcription from the mouse albumin promoter. Cell 47 767-776.

Guo S, Rena G, Cichy S, He X, Cohen P \& Unterman T 1999 Phosphorylation of serine 256 by protein kinase B disrupts transactivation by FKHR and mediates effects of insulin on insulin-like growth factor-binding protein-1 promoter activity through a conserved insulin response sequence. Journal of Biological Chemistry 274 17184-17192.

Hall RK, Yamasaki T, Kucera T, Waltner-Law M, O'Brien R \& Granner DK 2000 Regulation of phosphoenolpyruvate 
carboxykinase and insulin-like growth factor-binding protein-1 gene expression by insulin. The role of winged helix/forkhead proteins. Journal of Biological Chemistry 275 30169-30175.

Haruta T, Uno T, Kawahara J, Takano A, Egawa K, Sharma PM, Olefsky JM \& Kobayashi M 2000 A rapamycin-sensitive pathway down-regulates insulin signaling via phosphorylation and proteasomal degradation of insulin receptor substrate-1. Molecular Endocrinology 14 783-794.

Hendricks SA, Agardh CD, Taylor SI \& Roth J 1984 Unique features of the insulin receptor in rat brain. Journal of Neurochemistry 43 1302-1309.

Iwamoto K, Mori H, Okazawa H, Hashiramoto M \& Kasuga M 2002 Identification of a single nucleotide polymorphism showing no insulin-mediated suppression of the promoter activity in the human insulin receptor substrate 2 gene. Diabetologia 45 1182-1195.

Jiang ZY, Lin YW, Clemont A, Feener EP, Hein KD, Igarashi M, Yamauchi T, White MF \& King GL 1999 Characterization of selective resistance to insulin signaling in the vasculature of obese Zucker (fa/fa) rats. Journal of Clinical Investigation 104 447-457.

Jones PM \& Persaud SJ 1998 Protein kinases, protein phosphorylation, and the regulation of insulin secretion from pancreatic beta-cells. Endocrine Reviews 19 429-461.

Kanai F, Ito K, Todaka M, Hayashi H, Kamohara S, Ishii K, Okada T, Hazeki O, Ui M \& Ebina Y 1993 Insulin-stimulated GLUT4 translocation is relevant to the phosphorylation of IRS-1 and the activity of PI3-kinase. Biochemical and Biophysical Research Communications 195 762-768.

Kerouz NJ, Horsch D, Pons S \& Kahn CR 1997 Differential regulation of insulin receptor substrates- 1 and -2 (IRS-1 and IRS-2) and phosphatidylinositol 3-kinase isoforms in liver and muscle of the obese diabetic (ob/ob) mouse. Journal of Clinical Investigation 100 3164-3172.

Kido Y, Burks DJ, Withers D, Bruning JC, Kahn CR, White MF \& Accili D 2000 Tissue-specific insulin resistance in mice with mutations in the insulin receptor, IRS-1, and IRS-2. Journal of Clinical Investigation 105 199-205.

Kitamura T, Ogawa W, Sakaue H, Hino Y, Kuroda S, Takata M, Matsumoto M, Maeda T, Konishi H, Kikkawa U et al. 1998 Requirement for activation of the serine-threonine kinase Akt (protein kinase B) in insulin stimulation of protein synthesis but not of glucose transport. Molecular and Cellular Biology 18 3708-3717.

Kitamura T, Kitamura Y, Kuroda S, Hino Y, Ando M, Kotani K, Konishi H, Matsuzaki H, Kikkawa U, Ogawa W et al. 1999 Insulin-induced phosphorylation and activation of cyclic nucleotide phosphodiesterase 3B by the serine-threonine kinase Akt. Molecular and Cellular Biology 19 6286-6296.

Kohn AD, Summers SA, Birnbaum MJ \& Roth RA 1996 Expression of a constitutively active Akt Ser/Thr kinase in 3T3-L1 adipocytes stimulates glucose uptake and glucose transporter 4 translocation. Journal of Biological Chemistry 271 31372-31378.

Lee AV, Gooch JL, Oesterreich S, Guler RL \& Yee D 2000 Insulin-like growth factor I-induced degradation of insulin receptor substrate 1 is mediated by the $26 \mathrm{~S}$ proteasome and blocked by phosphatidylinositol 3'-kinase inhibition. Molecular and Cellular Biology 20 1489-1496.

Matsuda K, Araki E, Yoshimura R, Tsuruzoe K, Furukawa N, Kaneko K, Motoshima H, Yoshizato K, Kishikawa H \& Shichiri M 1997 Cell-specific regulation of IRS-1 gene expression: role of E box and C/EBP binding site in HepG2 cells and CHO cells. Diabetes 46 354-362.

Michael MD, Kulkarni RN, Postic C, Previs SF, Shulman GI, Magnuson MA \& Kahn CR 2000 Loss of insulin signaling in hepatocytes leads to severe insulin resistance and progressive hepatic dysfunction. Molecular Cell 6 87-97.

O’Brien RM \& Granner DK 1996 Regulation of gene expression by insulin. Physiological Reviews 76 1109-1161.
Orphanides G, Lagrange T \& Reinberg D 1996 The general transcription factors of RNA polymerase II. Genes and Development 10 2657-2683.

Pirola L, Bonnafous S, Johnston AM, Chaussade C, Portis F \& Van Obberghen E 2003 Phosphoinositide 3-kinase-mediated reduction of insulin receptor substrate-1/2 protein expression via different mechanisms contributes to the insulin-induced desensitization of its signaling pathways in L6 muscle cells. Journal of Biological Chemistry 278 15641-15651.

Rice KM, Turnbow MA \& Garner CW 1993 Insulin stimulates the degradation of IRS-1 in 3T3-L1 adipocytes. Biochemical and Biophysical Research Communications 190 961-967.

Roeder RG 1996 The role of general initiation factors in transcription by RNA polymerase II. Trends in Biochemical Sciences 21 327-335.

Rommel C, Clarke BA, Zimmermann S, Nunez L, Rossman R, Reid K, Moelling K, Yancopoulos GD \& Glass DJ 1999 Differentiation stage-specific inhibition of the Raf-MEK-ERK pathway by Akt. Science 286 1738-1741.

Rondinone CM, Wang LM, Lonnroth P, Wesslau C, Pierce JH \& Smith U 1997 Insulin receptor substrate (IRS)-1 is reduced and IRS-2 is the main docking protein for phosphatidylinositol 3-kinase in adipocytes from subjects with non-insulin-dependent diabetes mellitus. PNAS 94 4171-4175.

Rui L, Fisher TL, Thomas J \& White MF 2001 Regulation of insulin/insulin-like growth factor-I signaling by proteasomemediated degradation of insulin receptor substrate-2. Journal of Biological Chemistry 276 40362-40367.

Saad MJ, Araki E, Miralpeix M, Rothenberg PL, White MF \& Kahn CR 1992 Regulation of insulin receptor substrate-1 in liver and muscle of animal models of insulin resistance. Journal of Clinical Investigation 90 1839-1849.

Saad MJ, Folli F \& Kahn CR 1995 Insulin and dexamethasone regulate insulin receptors, insulin receptor substrate-1, and phosphatidylinositol 3-kinase in Fao hepatoma cells. Endocrinology 136 1579-1588.

Shimomura I, Matsuda M, Hammer RE, Bashmakov Y, Brown MS \& Goldstein JL 2000 Decreased IRS-2 and increased SREBP-1c lead to mixed insulin resistance and sensitivity in livers of lipodystrophic and ob/ob mice. Molecular Cell 6 77-86.

Shirakami A, Toyonaga T, Tsuruzoe K, Shirotani T, Matsumoto K, Yoshizato K, Kawashima J, Hirashima Y, Miyamura N, Kahn CR et al. 2002 Heterozygous knockout of the IRS-1 gene in mice enhances obesity-linked insulin resistance: a possible model for the development of type 2 diabetes. Journal of Endocrinology 174 309-319.

Sun XJ, Rothenberg P, Kahn CR, Backer JM, Araki E, Wilden PA, Cahill DA, Goldstein BJ \& White MF 1991 Structure of the insulin receptor substrate IRS-1 defines a unique signal transduction protein. Nature 352 73-77.

Sun XJ, Wang LM, Zhang Y, Yenush L, Myers MG Jr, Glasheen E, Lane WS, Pierce JH \& White MF 1995 Role of IRS-2 in insulin and cytokine signalling. Nature 377 173-177.

Sun XJ, Pons S, Wang LM, Zhang Y, Yenush L, Burks D, Myers MG Jr, Glasheen E, Copeland NG, Jenkins NA et al. 1997 The IRS-2 gene on murine chromosome 8 encodes a unique signaling adapter for insulin and cytokine action. Molecular Endocrinology 11 251-262.

Sun XJ, Goldberg JL, Qiao LY \& Mitchell JJ 1999 Insulin-induced insulin receptor substrate-1 degradation is mediated by the proteasome degradation pathway. Diabetes 48 1359-1364.

Tamemoto H, Kadowaki T, Tobe K, Yagi T, Sakura H, Hayakawa T, Terauchi Y, Ueki K, Kaburagi Y, Satoh S et al. 1994 Insulin resistance and growth retardation in mice lacking insulin receptor substrate-1. Nature 372 182-186.

Tsuruzoe K, Emkey R, Kriauciunas KM, Ueki K \& Kahn CR 2001 Insulin receptor substrate-3 (IRS-3) and IRS-4 impair IRS-1- and IRS-2-mediated signaling. Molecular and Cellular Biology 21 26-38. 
Ueki K, Yamamoto-Honda R, Kaburagi Y, Yamauchi T, Tobe K, Burgering BM, Coffer PJ, Komuro I, Akanuma Y, Yazaki Y et al. 1998 Potential role of protein kinase B in insulin-induced glucose transport, glycogen synthesis, and protein synthesis. Journal of Biological Chemistry 273 5315-5322.

Vassen L, Wegrzyn W \& Klein-Hitpass L 1999 Human insulin receptor substrate-2: gene organization and promoter characterization. Diabetes 48 1877-1880.

Waterfield MD \& Greenfield C 1991 Expression and properties of epidermal growth factor receptor expressed from baculovirus vectors. Methods in Enzymology 200 627-645.

White MF 1998 The IRS-signalling system: a network of docking proteins that mediate insulin action. Molecular and Cellular Biochemistry 182 3-11.

Withers DJ, Gutierrez JS, Towery H, Burks DJ, Ren JM, Previs S, Zhang Y, Bernal D, Pons S, Shulman GI et al. 1998 Disruption of IRS-2 causes type 2 diabetes in mice. Nature 391 900-904.
Yamauchi T, Tobe K, Tamemoto H, Ueki K, Kaburagi Y, Yamamoto-Honda R, Takahashi Y, Yoshizawa F, Aizawa S, Akanuma $Y$ et al. 1996 Insulin signalling and insulin actions in the muscles and livers of insulin-resistant, insulin receptor substrate 1-deficient mice. Molecular and Cellular Biology 16 3074-3084.

Zhang J, Ou J, Bashmakov Y, Horton JD, Brown MS \& Goldstein JL 2001 Insulin inhibits transcription of IRS-2 gene in rat liver through an insulin response element (IRE) that resembles IREs of other insulin-repressed genes. PNAS 98 3756-3761.

Zimmermann S \& Moelling K 1999 Phosphorylation and regulation of Raf by Akt (protein kinase B). Science 286 1741-1744.

Received 2 May 2003

Accepted 24 July 2003

Made available online as an

Accepted Preprint 3 September 2003 